\title{
African Controversy: The Inheritance of the Donatist Schism in Vandal Africa
}

\author{
by ROBIN WHELAN \\ Corpus Christi College, Cambridge \\ E-mail: rew47@cam.ac.uk
}

\begin{abstract}
A sense of an ending dominates accounts of African Christianity after the Vandal conquest of the 43os, not least as a result of the apparent disappearance of the Donatists in an Africa now ruled by Homoian Christians. In fact, the transfer from Donatist schism to new 'Arian controversy' more closely resembles the broader picture of Vandal Africa which has emerged from recent scholarship: significant continuity amid dynamic transformation. The cultural and rhetorical legacies of the Donatist schism were used by both parties (Catholic and Homoian) in Africa's new church conflict to present themselves as the true African Church.
\end{abstract}

7 he Roman Empire ended early in Africa. Between 429 and 439, the Vandals conquered Rome's African provinces; for the next century, Africa Proconsularis, Byzacena and much of Numidia would

AntTard $=$ Antiquité Tardive, CCSL $=$ Corpus Christianorum Series Latina; CSEL = Corpus Scriptorum Ecclesiasticorum Latinorum; HP = Victor of Vita, Historia persecutionis Africanae prouinciae, ed. S. Lancel, in Victor de Vita: Histoire de la persécution vandale en Afrique, Paris 2002; JECS = Journal of Early Christian Studies; $\mathrm{MGH}=$ Monumenta Germaniae Historica; SC = Sources Chrétiennes; UCM, BH = Universidad Complutense de Madrid, Biblioteca Histórica

All works of Fulgentius of Ruspe and Quodvultdeus of Carthage are cited from Fulgentius, Opera, ed. J. Fraipont, CCSL xci, xciA, Turnhout 1968, and Quodvultdeus, Opera, ed. R. Braun, CCSL lx, Turnhout 1976.

I would like to thank Christopher Kelly, Erika Hermanowicz and Ingrid Rembold for their helpful comments, and Éric Fournier for sending me his work in advance of publication. 
form a new polity ruled from Carthage, until the region's reconquest by the Emperor Justinian in 533-4. The events of the 43 os bear a heavy symbolism, representing for many observers, both contemporary and modern, the end of a world. Important recent work on Vandal Africa has convincingly rebutted this model of stark rupture, showing continued vitality in the former Roman provinces. ${ }^{1}$ The African successor state has somewhat belatedly been integrated into the broader revisionist project which has emphasised far-reaching continuities in other post-imperial kingdoms. ${ }^{2}$ Even so, the push to understand Vandal Africa as a dynamic polity still operating within a recognisably late Roman framework is only just gaining traction within the wider body of late-antique scholarship. The old image of the Vandals as a destructive and ultimately nihilistic force in Africa, bound up with modern notions of vandals and vandalism, remains hard to shift. 3

A similar sense of an ending has dominated accounts of African Christianity after empire. 4 The arrival of the Vandals undeniably brought about a major shift in African ecclesiastical politics. Like the other barbarian groups that established successor kingdoms, the new military elites of Africa were predominantly Homoian Christians. They adhered to a statement of doctrine which had lost out in the doctrinal controversies of the fourth century, the Creed of Rimini (359), which stated that God the Son was like (similis/öporos) God the Father.5 This Homoian creed was perceived as Arian heresy by the 'Catholic' churchmen of the fifth-century West, adherents to the Council of

1 A. H. Merrills (ed.), Vandals, Romans and Berbers: new perspectives on late antique North Africa, Aldershot 2004; G. M. Berndt, Konflikt und Anpassung: Studien zu Migration und Ethnogenese der Vandalen, Husum 2007; G. M. Berndt and R. Steinacher (eds), Das Reich der Vandalen und seine (Vor-)Geschichten, Vienna 2008; É. Fournier, 'Victor of Vita and the Vandal "persecution": interpreting exile in late antiquity', unpubl. Phd diss. California 2008; A. H. Merrills and R. Miles, The Vandals, Chichester 2010; J. Conant, Staying Roman: conquest and identity in Africa and the Mediterranean, 439-70o, Cambridge 2012.

${ }^{2}$ See, in particular, the helpful discussions in C. Wickham, Framing the early Middle Ages: Europe and the Mediterranean, 40o-8oo, Oxford 2005, 87-93, 635-44, 711-12, 720-3.

3 A. H. Merrills, 'The origins of "vandalism"', International Journal of the Classical Tradition xvi (2009), 155-75.

4 For a summary and elegant rebuttal see especially M. A. Handley, 'Disputing the end of African Christianity', in Merrills, Vandals, Romans, Berbers, 291-310.

5 For Vandals as Homoians see H. C. Brennecke, 'Lateinischer oder germanischer "Arianismus"? Zur Frage einer Definition am Beispiel der religiösen Konflikte im nordafrikanischen Vandalenreich', in H. Müller, D. Weber and C. Weidmann (eds), Collatio Augustini cum Pascentio: Einleitung, Text, Übersetzung, Vienna 2008, 125-44. For Homoian Christianity and Rimini see R. P. C. Hanson, The search for the Christian doctrine of God: the Arian controversy, 3 I $8-38$ I AD, Edinburgh 1988, 348-86, 557-97, and L. Ayres, Nicaea and its legacy: an approach to fourth-century Trinitarian theology, Oxford 2004, 133-66. 


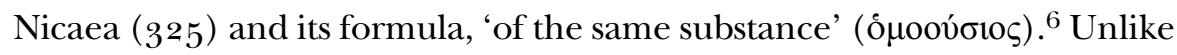
the other barbarian rulers, the Vandal kings adopted a consistent policy of promoting Homoian Christianity as orthodoxy within their realm. This meant the provision of considerable political, legal and financial support to a Homoian Church. It also led the kings to undermine the pre-existing Catholic Church, which the Homoians now treated as a heretical sect. A number of Catholic writers presented these measures as persecution though, as Éric Fournier has recently shown, the Vandal kings dealt with the Catholic Church according to late Roman methods for the punishment of heretics. 7 These dual policies seem to have met with not inconsiderable success. Homoian Christianity, already present in late Roman Africa, was a confession of Vandals and Romans alike. ${ }^{8}$ The new church politics had a profound effect on the literary output of African Christians. The

${ }^{6}$ Difficult terminological issues abound in this paper. Arian and Donatist are heresiological terms of abuse, not self-identifiers. When set against the term Catholic, they can be prejudicial, predetermining one side as the legitimate Church and the other as a schismatic or heretical sect. While the people called Donatists at least understood themselves and each other as a unified Church, the term Arian was used to describe and unite various non-Nicene doctrinal standpoints and confessional groups. One group, the Homoians, are widely referred to as Arians in the hostile surviving texts of the period, and still in some contemporary scholarship, although few scholars now use Arian as a simple descriptor and several wish to do away with it entirely. On this see especially, for Arians, R. Williams, 'R. P. C. Hanson's Search for the Christian doctrine of God', Scottish Journal of Theology xlv (1992), 101-1 1; Ayres, Nicaea and its legacy, 2, 13-14; D. M. Gwynn, The Eusebians: the polemic of Athanasius of Alexandria and the construction of the 'Arian controversy', Oxford 2007, 7; for Donatists, B. D. Shaw, 'African Christianity: disputes, definitions and "Donatists", in M. R. Greenshields and T. A. Robinson (eds), Orthodoxy and heresy in religious movements: discipline and dissent, Lampeter 1992, 5-34 (repr. in B. D. Shaw, Rulers, nomads and Christians in Roman North Africa, Aldershot 1995, XI); and, more generally, see C. Humfress, Orthodoxy and the courts in late antiquity, Oxford 2007, 217-42. I use Homoian for the adherents to that particular form of Christianity and Arian only in its correct form as a heresiological label (likewise also Homoousian, 'the heresy of opoov́бıs', the Homoians' term for the Catholics). Nicene is the best descriptor for the Homoians' opponents (not least because both parties saw themselves as 'Catholic'), but I also continue to use Catholic here to avoid confusion when casting back to the Donatist schism in which both sides appear predominantly to have been Nicene. As regards Donatist and Catholic, there are no widely accepted replacements (Brent Shaw has recently retracted his previous coinage - 'African Christians' - for Donatists: Sacred violence: African Christians and sectarian hatred in the age of Augustine, Cambridge $2011,5-6)$. I use both here, generally without scare quotes, in full awareness of the biases that they (almost inevitably) reproduce.

7 Fournier, 'Victor of Vita', esp. pp. 2 1 2-63. For Vandal 'persecution' see above all HP, Fournier, 'Victor of Vita'; T. Howe, Vandalen, Barbaren und Arianer bei Victor von Vita, Frankfurt 2007; and Merrills and Miles, Vandals, 184-92.

${ }^{8}$ D. R. Shanzer, 'Intentions and audiences: history, hagiography, martyrdom, and confession in Victor of Vita's Historia persecutionis', in Merrills, Vandals, Romans, Berbers, 286-8; Y. Modéran, 'La Notitia provinciarum et civitatum Africae et l'histoire du royaume vandale', AntTard xiv (2006), 165-82; Merrills and Miles, Vandals, 187, 194-5, 198-9; 
primary concern of contemporary Christian texts was how to protect the Catholic faith by dealing with the Arian (or, in the few Homoian texts that survive, Homoousian) heretics. A new 'Arian Controversy' was taking place in post-imperial Africa.

In this context, the schism which had dominated the affairs of the African Church ever since Constantine - and which continues to dominate modern scholarship on late-antique Africa-fades from view. After $c .430$ the Donatists become almost invisible. Of course, the absence of evidence is not evidence of absence. Brent Shaw has convincingly explained the relative paucity of references to Donatism and Donatists in Vandal Africa: these Christians had never defined themselves as Donatists and it was no longer effective to label them as such in the new ecclesiasticalpolitical climate.9 A number of anonymous texts plausibly from the Vandal period have been identified as coming from a Donatist milieu; ${ }^{10}$ and there are several generic heresiological references to Donatists. ${ }^{11}$ None the less, the individuals and groups who had been categorised in the past as 'Donatists' seem to have assimilated themselves to one side or other of the new ecclesiastical conflict in Vandal Africa between Catholics and

Conant, Staying Roman, 159-86, 193-5. For Roman Africa see N. B. McLynn, 'From Palladius to Maximinus: passing the Arian torch', JECS iv (1996), $4^{8} 5^{-8}$.

9 Shaw, 'African Christianity', 33. Curiously, 'Donatists' do resurface as a pressing contemporary issue in Africa some decades after the reconquest, in letters between Gregory the Great and African correspondents. At that time, they appear as a disciplinary problem within the Catholic Church. The precise reasons for the recycling of the label 160 years on are unclear, but it may imply a measure of Donatist-Catholic reconciliation in the interim: Gregory the Great, $e p p$. i. $72,75,82$; ii.39; iv.32, 35 ; vi.36, 62, 64, ed. D. Norberg, CCSL cxl, 1982; R. A. Markus, Gregory the Great and his world, Cambridge 1997, 188-202, summarising his earlier work (listed at p. 189 n. 7).

${ }^{10}$ A world chronicle, the Liber genealogus (ed. T. Mommsen, Chronica minora saec. IV. V. VI. VII., MGH Auctores antiquissimi ix, Berlin 1892, 154-96), went through three editions in this period: P. Monceaux, Histoire littéraire de l'Afrique chrétienne depuis les origines jusqu'à l'invasion arabe, VI: Littérature donatiste au temps de Saint Augustin, Paris 1922, 249-58; A. Dearn, 'Persecution and Donatist identity in the Liber genealogus', in H. Amirav and B. ter Haar Romeny (eds), From Rome to Constantinople: studies in honour of Averil Cameron, Leuven 2007, 127-35 (although the second and third editions may be Catholic: J. K. Parsons, 'The African Catholic Church under the Vandals, 429-533', unpubl. Phd diss. London 1994, 173 n. 107). Plausibly Vandal era texts: L. Dossey, Peasant and empire in Christian North Africa, Berkeley, CA 2010, 165-8. More speculatively, 'Donatist' churches have also been identified: see the judicious critique in S. Lancel, 'Le Sort des évêques et des communautés donatistes après la Conférence de Carthage en 41 1', in C. Mayer and K. H. Chelius (eds), Internationales Symposion über den Stand der Augustinus-Forschung, Würzburg 1989, $15^{\circ}$ with n. 4 .

${ }^{11}$ Quodvultdeus, Liber promissionum et praedictorum Dei ii.6.10, and De cataclysmo 5.7; Fulgentius, Liber de Trinitate ad Felicem 1.3, 1.6; Ps.-Fulgentius, Liber de Trinitate 2, line 58 , ed. J. Fraipont, Florilegia Biblica Africana saec. V, CCSL xc, 1961; Fastidiosus, Sermo (preserved as an attachment to Fulgentius, ep. ix) ii, lines $36-43$; Fulgentius, ep. ix.10; Gennadius of Marseille, De uiris inlustribus 74, ed. E. C. Richardson, Leipzig 1 896, with Dossey, Peasant and empire, 164 . 
Homoians, thus obscuring their presence. ${ }^{12}$ The very variety of these responses precludes any conclusion which could transcend the specific details of each report. For historians, if not necessarily for contemporaries, the year 430 marks the effective end of the Donatist schism.

There remains an overwhelming temptation to read the end of African Christianity into the disappearance of the Donatists (a proposition made all the more seductive by foreknowledge of subsequent developments in pre-modern North Africa). ${ }^{13}$ Yet in fact, the switch from 'Donatist schism' to new 'Arian Controversy' seems characteristic of the broader transition from Roman to Vandal rule. There is significant continuity in the ecclesiastical culture of Africa across the late-antique period. ${ }^{14}$ The new Christian conflict in Vandal Africa, just like its late Roman predecessor, was one between two Churches. ${ }^{15}$ And just like the Donatist schism, the rivalry between Catholic and Homoian church parties involved the use of sophisticated methods of Christian apologetic and polemic to contest Christian identity and the nature and status of the true Church before various audiences within African society. In these representations, the legacy of fourth-century Christological controversy naturally came to the fore. But at the same time, both sides appropriated the history, arguments and tactics of the Donatist schism to make their cases. The 'quarrel without end' may finally have been over, but another had sprung up just like it. ${ }^{16}$

\section{Only in Africa}

'The heavens thunder that the house of God is built throughout the whole world; and the frogs croak from their swamp, "We alone are Christians!"' ${ }^{7}$

${ }^{12}$ Fournier, 'Victor of Vita', $117-18,154-63$, and 'Rebaptism as a ritual of cultural integration', in D. Brakke, D. M. Deliyannis and E. Watts (eds), Shifting cultural frontiers in late antiquity, Aldershot 201 2, 243-54 (Donatists to Homoians); W. H. C. Frend, The Donatist Church: a movement of protest in Roman North Africa, Oxford 1952, 301; Markus, Gregory the Great, 191-3; Conant, Staying Roman, 180, 184 (Donatists to Catholics). See also Parsons, 'African Catholic Church', 43, 56-6o, and Howe, Vandalen, 263 n. 93.

${ }^{13}$ Handley, 'Disputing the end'. More recently, Brent Shaw, in his superlative study of religious conflict in late-antique Africa, has reverted to just such an interpretation: Sacred violence, 1, 802-4.

${ }^{14}$ Cf. R. A. Markus, 'Christianity and dissent in Roman North Africa: changing perspectives in recent work', in D. Baker (ed.), Schism, heresy and religious protest (Studies in Church History ix, 1972), 21-36.

${ }_{15}$ This is emphasised in Y. Modéran, 'Une Guerre de religion: les deux Églises d'Afrique à l'époque vandale', AntTard xi (2003), 21 1-44.

16 'rixa sine fine': Augustine of Hippo, Psalmus contra partem Donati 141, ed. R. Anastasi, Paris 1963 .

${ }^{17}$ Idem, Enarrationes in Psalmos 95.1 1, ed. E. Dekkers and J. Fraipont, CCSL xxxix, $195^{6 .}$ 
The Donatist schism in Africa developed from a dispute over the reconciliation of those who had collaborated during the 'Great Persecution' at the beginning of the fourth century. Two rival candidates, Caecilian and Maiorinus, were both elected to the see of Carthage, and the Emperor Constantine was petitioned for arbitration. The result was recognition for the party of Caecilian (the 'Catholics') against that of Maiorinus (the 'Donatists'). From the Council of Arles (314), the former was in communion with the transmarine Churches, while the latter was reciprocally disconnected from the rest of the imperial Church. ${ }^{18}$ The Donatists were not a purely African phenomenon: there were Donatist bishops of Rome, and scattered communicating groups elsewhere in the empire. ${ }^{19}$ Nor were they necessarily 'sectarian' in the sense of an aversion to the idea of a universal Christian institution. They merely thought that the other constituent bodies of the Catholic Church were polluted by communion with their adversaries, the 'Caecilianists' or 'traitors' (traditores) ${ }^{20}$ - so named for their purported actions, both literal and figurative, in handing over the Scriptures during persecution. Nevertheless, the disparity between the two Churches outside Africa became a symbol of Catholic self-identity. This argument also allowed for easy point-scoring: variations on it are almost ubiquitous in Optatus' and Augustine's anti-Donatist writings. ${ }^{21}$ The Catholics set out their communion with their transmarine brethren as proof that they were the true Church of Africa. Again and again they point out that the Catholic Church has (literally) to be universal; it cannot simply be in one province.

This model could easily be mapped on to church conflict in Vandal Africa. ${ }^{22}$ Once again, the Catholics' opponents could be portrayed as an almost exclusively African phenomenon. Homoian Christians in Vandal Africa do seem to have maintained contacts with other Homoian communities across the Mediterranean (certainly in the Eastern Empire

18 On all this see Shaw, 'African Christianity', 10-12; H. A. Drake, Constantine and the bishops: the politics of intolerance, Baltimore, MA 2000, $212-21$; S. Lancel, Saint Augustine, trans. A. Nevill, London 2002, 164-6; and M. Tilley, 'From schism to heresy in late antiquity: developing doctrinal deviance in the wounded body of Christ', JECS xv (2007), 13-18.

19 Frend, Donatist Church, 164, 195.

20 Ibid. 318 ; R. A. Markus, 'Africa and the orbis terrarum: the theological problem', in P.-Y. Fux, J.-M. Roessli and O. Wermelinger (eds), Augustinus Afer, Fribourg 2003, $325^{-7}$.

${ }_{21}$ Frend, Donatist Church, 206, 323-4; R A. Markus, Saeculum: history and society in the theology of St Augustine, Cambridge 1970, 113-14; Lancel, Augustine, 283; D. E. Doyle, 'Spread throughout the world: hints on Augustine's understanding of Petrine ministry', JECS xiii (2005), 233-40; E. T. Hermanowicz, Possidius of Calama: a study of the North African episcopate in the age of Augustine, Oxford 2008, 84.

${ }^{22}$ Cf. Modéran, 'Une Guerre', 36, and 'La Notitia', 169. 
and possibly also in Ostrogothic Italy). ${ }^{23}$ One extant Homoian text, the early sixth-century sermon of a deacon Fastidiosus, who had converted from Nicene Christianity, also claimed Catholicity for the Homoian faction. ${ }^{24}$ Still, only in Africa could the Homoians plausibly claim to be a Church in the ascendancy.

As a result, the transmarine argument appears frequently in Catholic anti-Arian polemic in Vandal Africa. ${ }^{25}$ It surfaces numerous times in the literary corpus conventionally attributed to Quodvultdeus, bishop of Carthage at the time of the Vandal conquest, who was sent into exile in southern Italy by Geiseric, and died there. ${ }^{26}$ For instance, in a sermon On the creed, the preacher demanded of an imaginary opponent, 'how is it that you exult, Arian, that you hold the truth, when an evil error, separating you from Catholic doctrine, testifying that you are a heretic, and separating you from the communion of the whole world, condemns you to one corner?'27 The Catholics were the Church everywhere; the Arians, stubborn deviants who had painted themselves into their own little African corner. At the other end of the century of Vandal rule in Africa, Fulgentius, bishop of the coastal town of Ruspe in Byzacena $(c .508-33),{ }^{28}$ received a request for guidance on how to defend the Catholic faith made by an otherwise unknown correspondent called Felix. In his Book on the

${ }^{23}$ For the East see HPii.4, 24; for Italy, the possibly African Homoian sermons in the late fifth- or early sixth-century ms Verona Bibl. Capit. LI (49): De solemnitatibus, ed. R. Gryson, Scripta Arriana latina I, CCSL lxxxvii, 1982.

${ }^{24}$ Fastidiosus, Sermo iii. 43-4; v.88-9o; Fulgentius, ep. ix, Victoris 4, lines 72-3. (Fulgentius ep. ix is a composite affair in the edition, comprising the letter of Fulgentius' correspondent, Victor, alerting him to Fastidiosus' sermon; a copy of the sermon itself; and Fulgentius' response.)

${ }^{25}$ Parsons, 'African Catholic Church', ${ }_{15} 6$. There are also some attempts to make Arianism into a 'foreign' Christianity as opposed to 'African' Catholic Christianity, for example, 'Or perhaps you have brought a new faith, a new baptism, a new god from the transmarine parts?': Quodvultdeus, Adversus quinque haereses $7 \cdot 42$.

${ }_{26}$ Quodvultdeus, Contra Iudaeos, paganos et Arrianos 20.1; De symbolo iii.13.4; Liber promissionum D.5.7. The attributions to Quodvultdeus, both of the totality of this sermon collection (ed. Braun: 225-486) and the Liber promissionum. (ibid. 1-223), have been contested. Even if not Quodvultdeus, it is generally agreed that the author or authors are contemporary African Nicene clerics. See R. Braun, Quodvultdeus: Livre des promesses et des prédictions de Dieu, SC 101, Paris 1964, 11-113; A. Isola, I cristiani dell'Africa vandalica nei sermones del tempo (429-534), Milan 1990, 10 n. 6; Parsons, 'African Catholic Church', 135-6, 140, 162 n. 31, 164 n. 37; D. Van Slyke, Quodvultdeus of Carthage: the apocalyptic theology of a Roman African in exile, Strathfield, NSW 2003, 48-63. $\quad{ }^{27}$ Quodvultdeus, De symbolo iii.9.9.

${ }_{28}$ For Fulgentius see H.-J. Diesner, Fulgentius von Ruspe als Theologe und Kirchenpolitiker, Stuttgart 1966; Y. Modéran, 'La Chronologie de la Vie de Saint Fulgence de Ruspe et ses incidences sur l'histoire de l'Afrique vandale', Mélanges de l'Ecole française de Rome: Antiquité cv (1993), 135-88; C. Leyser, “'A wall protecting the city”: conflict and authority in the Life of Fulgentius of Ruspe, in A. Camplani and G. Filoramo (eds), Foundations of power and conflicts of authority in late-antique monasticism, Leuven 2007, 17592; and Merrills and Miles, Vandals, 196-203. 
Trinity to Felix, Fulgentius used this query as a springboard for a developed statement of "the faith ... which hitherto the holy Church holds throughout the whole world'. ${ }^{29}$ This faith was preached from the apostolic cathedrae of Rome, Antioch, Alexandria and Ephesus, and in Jerusalem:

Therefore, compel the Arians, Donatists, Nestorians, Eutychians, Manichaeans and the remaining heretical plagues to communicate with these churches... For they do not agree with them, because through the perversity of their faith they want to be divided off from the unity of the Church in one part. $3^{\circ}$

In Catholic polemic, the Arians had joined the Donatists as African separatists.

The argument was employed not only in texts intended for a Catholic audience, but also in public controversy with the Homoians. In 483 the Vandal King Huneric sent out an edict convoking a conference at Carthage between the two church factions the next year, in what appears to have been a deliberate re-enactment of the conference of 411 between the Catholics and Donatists. ${ }^{1}$ Seeking better terms for the Catholic party, the then bishop of Carthage, Eugenius, lobbied the king through his superintendent, Obadus. In a letter preserved by Victor of Vita, Eugenius stated that the conference

ought also to be made known to those in all of the transmarine parts who are our colleagues in one religion and communion, because all obey his [sc. Huneric's] rule everywhere, and particularly because this is a matter for the whole world, and not just for the African provinces alone. $3^{2}$

Eugenius' request both alluded to the superior Mediterranean numbers of the Catholic party and sought recourse to that strength in the proposed conference at which, just as in 411 , numbers played an important role.33 At the conference itself, the Catholic bishops read out a long statement of their doctrine entitled The book of the Catholic faith. It ended with a defiant statement of universality: 'this is our faith, founded on evangelical and apostolic traditions and the communion of all the Catholic churches which are in this world'.34

The similarity of the Donatists and Homoians in geographical distribution allowed Catholic polemicists to retread a well-worn argument. Still, there were important new elements which differentiated the two sets of African Christians. Catholic writers took account of these changes and

${ }^{29}$ Fulgentius, Ad Felicem 1.2, lines 12-16.

$3^{\circ}$ Ibid. 1.3, lines 21-5.

${ }^{31}$ HP ii.39; Victor: n. 7. For the re-enactment see Parsons, 'African Catholic Church', 232-7, and Fournier, 'Victor of Vita', $113^{-15}, 253^{-60}$, and 'Victor of Vita and the Conference of 484 : a pastiche of 411 ?', Studia Patristica lxii. $395^{-408}$, here at pp. 403-6. $\quad 3^{2}$ HP ii.41; cf. Parsons, 'African Catholic Church', 231.

33 Modéran, 'La Notitia', 168-9. For the 'numbers game' in 411 see Shaw, Sacred violence, $5^{69-73}$.

34 HP ii. $5^{6-101}$ at ii.101. 
adapted their claims to universal Christianity accordingly. One anonymous Catholic author used the transmarine argument in a new form to defend his faction from Homoian attacks against the key Nicene Christological term,

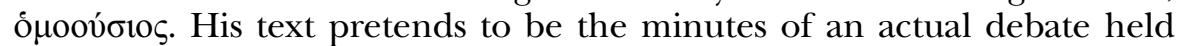
between Augustine and a Homoian imperial count called Pascentius, but was in fact an artful fiction produced in Vandal Africa. 35 It ends with a long speech by 'Augustine' rebutting Homoian descriptions of the Catholics as 'Homoousian' heretics which, at least to the author's mind, hinged in part on the Greekness of the word: 'Far be it that we, remaining Catholics in the whole world, should be embarrassed that we are called, according to the true faith of one and the same substance, by some people who do not understand the Greek word, the Homoousians, because we rejoice that we are called, from the Greek name of Christ, Christians. '36

The history of previous conflicts between Nicene and Homoian Christians was also cast in the mould of anti-Donatist portrayals of Catholicity. The preface to an anonymous collection of biblical testimonia On the Trinity (wrongly attributed to Fulgentius of Ruspe in the seventeenth century, but still called Pseudo-Fulgentius for convenience) adapts these Catholic arguments to contest Homoian depictions of the twin Council of Rimini and Seleucia (359) as universal and orthodox. Homoian Christians had apparently been claiming that Rimini was more valid than Nicaea because it had a far greater number of attendees (830 as opposed to 318).37 Ps.-Fulgentius glossed this claim by setting the two councils in an apologetic narrative of the fourth century. At first, "homoousios held fast in a few'; then it became known to 'other bishops constituted through the space of the whole world'. $3^{8}$ Nicaea thus fulfilled God's promise that his Church would increase. 39 Rimini, on the other hand, had no such positive progression:

But if later they met in such a multitude at Rimini, as they assert, the bishops of that sect would have multiplied through the world, their congregations would have grown, such a faith would even have occupied empires. But when the cunning of that fraud was recognised through prudent and most proven men, thus homoousios was confirmed, that we might discern that barely the remnants of Rimini have remained to prove the Catholics. $4^{\circ}$

Just like the two factions' fifth-century fortunes, so too the fourth-century history of the Catholics and Arians was harnessed to show that one was a

35 Collatio Augustini cum Pascentio Ariano, ed. H. Müller, D. Weber and C. Weidmann, Collatio Augustini cum Pascentio: Einleitung, Text, Übersetzung, Vienna 2008, with excellent introduction and commentaries. See also U. Heil, 'Augustin-Rezeption im Reich der Vandalen: die Altercatio sancti Augustini cum Pascentio Arriano', Zeitschrift für Antikes Christentum xi (2007), 6-29. $\quad 3^{6}$ Collatio Augustini cum Pascentio 15, lines 152-6.

37 Ps.-Fulgentius, De Trinitate 3. An inflated figure: cf. Hanson, The Search, 376.

$3^{8}$ Ps.-Fulgentius, De Trinitate 3 , lines 74-6.

$4^{\circ}$ Ibid. 3 , lines $76-82$. 
Church across the whole world, the other a heretical sect barely even resident in a part of it.

This Catholic schema placed the opponents whom they saw as Arians in the role previously occupied by the Donatists. Whether an analogy between the two heretical groups was always intended is unclear. In late-antique heresiology the association of opponents with previously condemned heretics was a recurrent strategy. $4^{1}$ So, for instance, Cyril of Alexandria accused Nestorius of being the new Arius; and the labels 'Arian' and 'Donatist' in and of themselves tarnished the accused with the blackened reputation of eponymous deviants. $4^{2}$ In his book for Felix, Fulgentius of Ruspe made the connection explicit, asking, "what do the unhappy people say who, cut off from the Church of God and impenitent in their hearts, contradict the Church, and since they try to split that same Church, which is the seamless tunic of the lord, are themselves torn more easily?' 43 After this richly ambiguous rhetorical question-are these schismaticsounding individuals Arians or Donatists? - Fulgentius clarified: he was referring to both: 'That man says that he is redeemed by the blood of Christ. So was the blood of Christ shed solely for the Arians or only for the Donatists?' 44

Others, however, kept this relationship implicit. What can be said is that Catholic portrayals of Arianism appealed to a lexicon of heretical characteristics which had been drummed into their African congregations in the decades prior to the Vandal conquest. Even if the reader were not supposed to think that the Arians were Donatists, he was to understand them as like them, and thus similarly deviant. The persistent use of arguments about universality which had been ubiquitous during the Donatist schism shows a fundamental continuity in the manner in which African Catholic clerics perceived their Church and its dissenters.

\section{The rebaptisers}

Baptism represented another highly charged issue within the Donatist schism.45 In common with various other late-antique Christian groups and individuals, the Donatists practised (re)baptism for Christians baptised

$4^{1}$ For example see J. R. Lyman, 'Heresiology: the invention of "heresy" and "schism"', in A. Casiday and F. W. Norris (eds), The Cambridge history of Christianity, II: Constantine to c. 6oo, Cambridge 2008, 296-313 at p. 309 .

$4^{2} \mathrm{~S}$. Wessel, Cyril of Alexandria and the Nestorian controversy: the making of a saint and a heretic, Oxford 2004, 126-37, 212-24, and see n. 6 above.

43 Fulgentius, Ad Felicem 1.5, lines $5^{2-5}$. $\quad 44$ Ibid. $1.5^{-6}$, lines $5^{6-8 .}$

45 Lancel, Augustine, 172; Markus, 'Africa and the orbis terrarum', 322-5; C. García Mac Gaw, Le Problème du baptême dans le schisme donatiste, Paris 2008; Shaw, Sacred violence, 102-3. 
outside their Church. ${ }^{6}$ Baptism by traitors or those in communion with them was invalid. For the Donatists, it was as if it had not happened; hence, what to Catholic observers was a repetition which contravened the proof-text 'one God, one faith, one baptism' (Ephesians iv.5) would for Donatists have been that single true baptism. 47 The Catholics saw Donatist baptism as similarly inefficacious but, like their transmarine colleagues, merely required the imposition of hands for those entering the Catholic fold. Optatus and Augustine may have produced varying theological justifications for this practice, but both proceeded from the principle that the Donatists' second baptism was a grievous error. $4^{8}$

This divergence in ritual praxis came to embody the broader dispute. It took on an added significance around the turn of the fifth century. 49 In this period prominent Catholics lobbied the state, seeking the implementation of Theodosius' anti-heretical legislation against the Donatists. Previously, the Catholics seem to have understood their opponents' error as schism rather than heresy. $5^{\circ}$ Notwithstanding the overlap between the two labels, $5^{1}$ in the neat categorisation of late Roman law schism was not subject to the same harsh penalties as heresy. As part of an attempt to turn schismatics into heretics, the Catholics seized on the issue of rebaptism as a heretical praxis. This was a contentious claim which ignored African Christian tradition; rebaptism seems to have been a normative practice for many communities going back to the third century. ${ }^{2}$ It also may have given the issue a prominence disproportionate to its role in Donatist self-definition (that is, over and above the fundamental Christian requirement of correct baptism). Nevertheless, the plan worked, as Honorius' edict of 12 February 405 and subsequent imperial laws

$4^{6}$ For a succinct illustration of the variety of these individuals, groups and contexts for rebaptism see E. Ferguson, Baptism in the early Church: history, theology, and liturgy in the first five centuries, Grand Rapids, Mr 2009, 45 1, 470, 575-6, 761.

47 Frend, Donatist Church, $136-7$; Hermanowicz, Possidius, 144 n. 37.

$4^{8}$ García Mac Gaw, Le Problème du baptême, 239-77.

49 For what follows see Humfress, Orthodoxy and the courts, 266-8; Hermanowicz, Possidius, 89, 97-155; C. Buenacasa Pérez, 'La Persécution du donatisme et l'imposition de l'orthodoxie en Afrique du Nord (Ive-ve siècles): comment effacer la mémoire des hérétiques?', in S. Benoist (ed.), Mémoire et histoire: les procédures de condamnation dans l'Antiquité romaine, Metz 2007, 225-42; García Mac Gaw, Le Problème du baptême, 238; and Shaw, Sacred violence, 532-9.

$5^{\circ}$ This was the constant refrain of Optatus of Milevis, Contra Parmenianum, especially book i, ed. M. Labrousse, SC cdxii-iii, Paris $1995^{-6 .}$

$5^{1}$ S. L. Greenslade, Schism in the early Church, 2nd edn, London 1964, 15-29; Tilley, 'From schism to heresy'.

$5^{2}$ J. Patout Burns, 'On rebaptism: social organisation in the third century Church', JECS i (1993), 367-403. For the influence of these debates during the Donatist schism see García Mac Gaw, Le Problème du baptême, 239-99, and Lancel, Augustine, 172, 280-4. 
demonstrate. 53 For both imperial chancery and Catholic polemicists, the Donatists were now rebaptisers and heretics.

Vandal Africa saw the same Catholic complaints about heretical rebaptism. Now, however, Catholic polemicists made the repetition of baptism a major feature of Arian heresy. 54 In some works it takes on an overriding importance. Victor of Vita and Quodvultdeus both highlight the practice as one of the worst Arian characteristics and portray its enactment as a form of martyrdom. 55 Most strikingly, a universal chronicle written in Carthage in $496 / 7$ singled out rebaptism as the reason contemporary Arians were worse than their fourth-century predecessors:

During the great discord in the Roman Empire ['regno Romano'] up until Theodosius, by whom they were driven out from all the churches, they had not dared to commit this. By this act today the enemy brings about those things to come: they are witnesses (testes) of the Church, although their bodies are not butchered by the sword, but rather their spirits by water. $5^{6}$

The African Catholic image of heresy had not changed; heretics were rebaptisers, whether Donatist or Arian.

This is not to suggest that Homoian Christians did not indeed require Christians entering their congregations to undergo the rite once more. 57 The sheer volume and variety of Nicene complaints excludes the possibility of Arian rebaptism in Vandal Africa being a solely heresiological invention. Again, what is less clear-cut is whether Catholic foregrounding of the issue is an accurate reflection of an importance to Homoian Christian selfidentity beyond that of a valid baptism to any Christian. This emphasis seems at least as much a result of continuity in African Catholic thinking about heresy since the late Roman period. By focusing on rebaptism,

53 Codex Theodosianus xvi.6.4-5 (405); xvi.5.37-41 (405-7); xvi.5.43-4 (407-8); xvi.5.46 (409); xvi.5.52 (412); xvi.5.54-5 (414), ed. T. Mommsen and P. M. Meyer, Berlin 1904.

54 For important discussion of rebaptism in Vandal Africa, if with a different approach to that suggested here, see Fournier, 'Rebaptism'.

55 HP i.19-2 1, 30-3; ii.29; iii.23, 27, 36, 45-52; Quodvultdeus, Liber promissionum i. $3_{6.5}$; ii.19.35, D.8.16, D.14.23; Contra Iudaeos 19, Aduersus quinque haereses 7.38-46, De symbolo I 13.6-8, De ultima quarta feria $6.15^{-24}$, De accedentibus ad gratiam II $11-13$ at 1 2.6, De tempore barbarico I 8.4-13, II 14.3-4.

$5^{6}$ Epitome Carthaginiensis, ed. T. Mommsen, Chronica minora saec. IV. V. VI. VII., MGH Auctores antiquissimi ix, Berlin 1892, 496, with C. Courtois, Les Vandales et l'Afrique, Paris 1955, 407-8. Mommsen provides a part edition, as does R. Steinacher in 'The socalled Laterculus regum Vandalorum et Alanorum: a sixth-century African addition to Prosper Tiro's Chronicle?', in Merrills, Vandals, Romans, Berbers, 166-8. The full text is in UCM, BH, MS 1 34, fos 42r-47v (http://alfama.sim.ucm.es/dioscorides/consulta_libro. asp?ref=B20920246\&idioma $=1$ ).

57 Although see Fulgentius, De remissione peccatorum i.22, where some Catholics attend Homoian services 'without the repetition of baptism'. 
Catholic authors frontloaded a custom that they and their imagined audiences perceived as a major characteristic of heretics.

When Catholics censured Arian rebaptism, they did so as if they were arguing against Donatists. As Jonathan Parsons has noted, the scriptural passages Ephesians iv.5 ('one God, one faith, one baptism') and John xiii.10 ('he who has been washed once does not need to be washed again') were again brandished as proof-texts. $5^{8}$ For example, in his Against the five heresies, Quodvultdeus built towards a climax by describing an imagined Arian rebaptism in the guise of a martyr act. 'He builds a cave, and chokes the Catholic there, he calls a Christian a pagan, he forces a baptism upon the baptised, against that which is written, he who has been washed once does not need to be washed again. The man shouts: "I am a Christian! Why do you tell me that I am not?"'59 The passage is very reminiscent of Optatus' arguments against Donatist rebaptism, which glossed the same scriptural citation and made the same complaint about calling baptised Catholic Christians pagans. ${ }^{60}$ Fulgentius of Ruspe repeated both points in his Abecedarium, an alphabetical psalm which through its very literary structure made the Donatists a referent for African Arians. For the song sought to imitate Augustine's polemical Psalm against the party of Donatus, another ABC-er. ${ }^{61}$ The Homoians's baptismal practices aligned them with earlier opponents of Africa's Catholic faction. Catholics like Fulgentius did not hesitate to exploit the resemblance.

\section{'Some throw at us the persecutions of the Donatists'62}

'And it came to pass for the Donatists as for the accusers of Daniel. For just as the lions were turned back upon the latter, so were the laws on those people who, by them, had wished to oppress the innocent. ${ }^{63}$

The Catholics were not alone in appealing to the late Roman heritage of African Christianity. The Donatists appear in two extant texts which present a Homoian perspective: the sermon of Fastidiosus, preserved in a letter of Fulgentius of Ruspe which replied to it, and Huneric's edict of 484 against Homoousian heresy. Like their Catholic counterparts, these Homoian writers can be seen using the history and heresiology

$5^{8}$ Parsons, 'African Catholic Church', $15^{6-7 .}$

59 Quodvultdeus, Aduersus quinque haereses 7.38-9. See also Passio septem monachorum 3, 8, ed. Lancel, in Persécution vandale, letter of Eugenius in Gregory of Tours, Libri historiarum Xii.3, ed. W. Arndt and B. Krusch, MGH Scriptores rerum Merovingicarum i. 1, Hanover 1884. 6o Optatus, Contra Parmenianum v.3, iii.1 1.

${ }^{61}$ Fulgentius, Abecedarium $67-73$, ed. A. Isola, Salmo contro $i$ vandali ariani, Corona patrum 9, Turin 1983. For the relationship between the texts see Isola, Salmo, 20-2, and Shaw, Sacred violence, 482 with nn. ${ }^{8} 3^{8-9}$, and pp. $475^{-89}$ for a sympathetic reappraisal of Augustine's psalm. $\quad 62$ Ps.-Fulgentius, De Trinitate 4, lines $113^{-14}$.

63 Augustine, ep. clxxxv.7, ed. A. Goldbacher, CSEL lvii, Vienna 1911. 
of the Donatist schism to legitimise their self-professed status as the true Christians of Africa. ${ }^{64}$ They used this recent past in a manner which deliberately discomfited their opponents, whose actions under imperial favour sat uneasily with their present claims to be the Church that suffered persecution.

In his sermon, Fastidiosus equated the Catholics with their erstwhile opponents. ${ }^{6} \mathrm{He}$ attributed to heretics a uniform psychological profile: they were obstinate and self-harmed with the 'life-giving words', the 'surgical instruments' by which they could be saved. ${ }^{66}$ Fastidiosus went on to state that 'for a long time now, a bipartite error has crept in': the Homoousians and the Donatists. In spite of their previous differences, both sets of heretics were fitted to the same mould. This was a bold and farreaching polemical claim. Over many decades African Catholics had worked to turn the term Donatist into a powerful symbol of obstinate Christian error. Fastidiosus now tarred the Homoousians with their own brush.

In his reply to the sermon, Fulgentius claimed that Fastidiosus had stolen the description of Donatism from his own work; but he did not tackle the broader point that the deacon sought to make. ${ }^{67}$ Elsewhere, a Catholic cleric did respond to Homoian use of the African Christian past. The royal edict of 484 proscribing the Catholics as Homoousian heretics justified itself in part by the legal precedent and historical lessons of imperial edicts against the Donatists. The preface to Ps.-Fulgentius' Book on the Trinity responded to this claim as part of what seems to be a point-by-point refutation of the law. ${ }^{68}$ Huneric's edict classified Nicene Christians as Homoousian heretics in the aftermath of a conference where they had been ordered to show that word in the Bible; ${ }^{69}$ Ps.-Fulgentius stated that 'indeed he who made that libellus, conceived with a savage mind, judged that the mass of divine testimonies as much from the New as the Old Testament must oppose homoousios'. $7^{\circ}$ Huneric twice adverted to the universal Council of Rimini-Seleucia as an authorising standard of orthodoxy, emphasising its attendance figures; ${ }^{71}$ Ps.-Fulgentius deprecated the idea of numbers proving Rimini to be a universal council and orthodox

${ }^{6}$ Cf. Merrills and Miles, Vandals, 199.

$6_{5}$ For this see Fastidiosus, Sermo ii. 27-43.

66 On such medical imagery see M. Gaddis, There is no crime for those who have Christ: religious violence in the Christian Roman Empire, Berkeley, CA 2005, 146-7.

67 Fulgentius, $e p$. ix at ix. 10.

68 The only attempt to date this text more precisely of which I am aware is Parsons, 'African Catholic Church', 45-6, followed by Fournier, 'Victor of Vita', ${ }_{1} 5^{6-7}$. Parsons places the text in a 'transition period' early in Vandal rule because of its references to Donatists; I suggest that the text was written in response to, or within the milieu of, Huneric's edict of 484 .

$7^{\circ}$ Ps.-Fulgentius, De Trinitate 2, lines 23-6.

69 HP iii. $3^{-1} 4$ at iii.4-5, 12. 
creed. $7^{2}$ Even if the scanty survival of contemporary Homoian texts and the absence of an explicit reference to the edict preclude certainty that this was a direct reply, the close match of content makes clear that the Book on the Trinity represents, at the very least, a response to Homoian arguments in use when the law was framed.

The theme of Huneric's edict, announced in its prologue, is an ironic echo of Augustine's castigation of the Donatists in letter 185: 'It is approved that it is of the triumphal power of royal majesty to turn round (retorquere) evil designs against their authors: for anyone who contrives anything depraved brings upon himself what he incurs.'73 The law drew on the corpus of late Roman anti-heretical legislation and in particular Honorius' edicts against the Donatists. 74 Huneric made explicit reference to these earlier laws and problematised their use against Homoousians: 'Therefore it is necessary and most just to turn round against them that which is contained in their laws ['quod ipsarum legum continentia demonstratur'] which then, since the emperors of various times were induced to error with them, happened to be promulgated.' 75 The text summarised this content (iii.8-11) before stating that the Homoousians were to be subject to these punishments (iii.12). At the centre of the summary is a long schedule of fines differentiated according to the legal status of the convicted, taken verbatim from Honorius' edict of 412 following the Conference of Carthage (411). $7^{6}$ The prominence of this particular section, in an edict promulgated in the aftermath of a Carthaginian Conference modelled on the confrontation of 411 , clarifies the earlier reference to retribution for the previous actions of African Catholic Christians. It seems that it was imperial sanctions against Donatism that the framer had specifically in mind. 77 The laws that African Catholics had gained through sympathetic emperors against heretical opponents - and against the Donatists in particular-were now used both as legal precedent and moral justification for their own punishment. The coercive powers of the state, used so effectively by the Catholics in the first decades of the fifth century, were turned round on them-and, so Huneric claimed, they had only themselves to blame.

$7^{2}$ Ps.-Fulgentius, De Trinitate 3.

73 HP iii.3; cf. Diesner, Fulgentius von Ruspe, 40, and Howe, Vandalen, 275-6, 368 , connecting Huneric's policies to Augustine's doctrine of coge intrare.

74 M. Overbeck, Untersuchungen zum Afrikanischen Senatsadel in der Spätantike, Frankfurt 1973, 77-9; Lancel, Persécution vandale, 177-9 nn. 372-80; Fournier, 'Victor of Vita', 75 n. 3, 157; 'Rebaptism', 25o; and 'Conference of 484', 395-401; Conant, Staying Roman, 168-9 with n. 167. 75 HP iii. 7 .

$7^{6}$ HP iii.1 o; CTh xvi. $5.5^{2}$ preface; Lancel, Persécution vandale, 315 n. 378.

77 Parsons, 'African Catholic Church', 57, and Fournier, 'Victor of Vita', $158-9$, suggest that a Donatist convert to 'Arianism' mentioned in a coda to HP as a transuersor legis had guided Huneric to these laws. 
In his Book on the Trinity, Ps.-Fulgentius disputed this interpretation of the Catholics' role reversal. It is clear from the text that this was not an easy task: the awkward combination of past triumphalism and present marginalisation required a carefully articulated statement of ecclesiology. $7^{8}$ The anonymous Catholic author set out to clarify his statement on God's promised increases to his Church, lest his Homoian opponents could claim that the status of the true Church had been conceded to them 'through this oppression' (best understood as his polemical gloss on their current political favour). He argued that the Church was verified not by unjust rewards (quoting Jeremiah xvii.11), but rather by 'tribulations and persecutions'; exile, proscription, captivity and torture witnessed the flourishing of that faith. This argument took Ps.-Fulgentius intriguingly, even dangerously, close to Donatist territory. As the Donatist bishop Parmenian famously put it during the conference of $4^{11}$, 'the true Catholic Church is with us; the one which suffers persecution, not the one which inflicts it'.79 Ps.-Fulgentius, responding either to Huneric or to the Homoians more generally, saw the trap for the Catholics in too crude a claim to be the persecuted Church in Vandal Africa: 'But I see some about to produce contradictions, and to throw at us the persecutions of the Donatists, whose fury did violence to the laws, and who endured the laws to the full.' Qualification was thus necessary. His response was to dismiss the comparison out of hand. 'But if the Catholic mother received some of them to her pious bosom, she did so without the injury of any baptism, without any quarrel and without any insult to the Holy Spirit, that they who were converted willingly would grieve that Catholic charity had been hidden from them for so long.' For Ps.-Fulgentius, the two cases were fundamentally different: for in each one the true Church played a different role, whether rightful dispenser of salutary coercion or proven sufferer of persecution. ${ }^{80}$ The identity of the Church did not change even if its circumstances did. Ps.-Fulgentius artfully calibrated his ecclesiology to explain the activities of the Catholics in both the Donatist schism and the new Arian controversy in which they were engaged. He was forced to do so by the skilful manner in which Huneric, and the Homoians whose concerns the king reflected, were exploiting the recent past of African Christianity.

The Vandal conquest of Africa reshaped the landscape of African Christianity. The split between Catholic and Donatist factions which had been its dominant feature for over a century no longer seemed quite

${ }^{7}$ For what follows see Ps.-Fulgentius, De Trinitate 4, lines 97-1 19.

79 Gesta concilii Carthaginiensis iii.22, ed. S. Lancel, Actes de la Conférence de Carthage en $4 I I$, iii, SC ccxxiv, Paris 1975 .

80 An echo of Augustine on true and false persecution: Gaddis, There is no crime, 139; Fournier, 'Victor of Vita', 236-9; T. Sizgorich, Violence and belief in late antiquity: militant devotion in Christianity and Islam, Philadelphia, PA 2009, 62-4, 75-7. 
so wide. A new rift, between Nicene and Homoian church parties, became the topic most worthy of discussion, explanation and polemic for Christian authors plotting their own topographies of orthodoxy and heresy. ${ }^{81}$ For Catholic apologists, priorities inevitably changed. Unsurprisingly, Christological and Trinitarian doctrine gained a new importance. The history of the Church looked very different to a Catholic writing in the 490 s than it had a century earlier. The anonymous Carthaginian chronicler devoted his account of the fourth century almost exclusively to Nicene-Arian conflict. Within that narrative, the Donatists are reduced to a sentence. There is no better indication of the change in the times than his pen-picture. Donatus was 'an equal of Arius [non impar Arrio]' - not the other way around - and 'Optatus explained the beginning and end of his heresy in a work of seven books'. ${ }^{82}$ For the chronicler, Donatism constituted a purely historical phenomenon; it was long gone.

Yet the disappearance of the 'Donatists' is a misleading metaphor for the process which transformed the Church in post-imperial Africa. Church politics changed, yet they also remained the same. Two church parties contested the title of the true Church of Africa. In a voluminous literary struggle, of which one side is almost completely lost, the two factions traded blows and sought to reinforce the boundaries of their own Christian communities. The conduct of doctrinal controversy in Vandal Africa was steeped in the history, the methods and, above all else, the heresiology of the late antique Church. Disputants drew on this distinctive intellectual culture, using polemical tropes, rhetorical strategies and (often sly) tactics familiar from any number of fourth- and fifth-century Christian conflicts.

Within this broader context, both sides located themselves and their opponents in relation to the combatants of the Donatist schism. Nicene authors used two fundamental anti-Donatist arguments - the universality of Catholicism and the heretical nature of rebaptism - to restate their own Catholicity to audiences attuned to such claims by decades of exhortation and polemic. At the same time, their new opponents were made to look like their old Donatist sparring partners. While recognising, explaining and attacking the features of those Homoian Christians that made them exclusively and specifically 'Arian', Catholic authors often emphasised characteristics shared with the Donatists. Nicene Christians did not have a monopoly on the powerful Christian cultural resources of late Roman Africa. Homoian authors turned that legacy back on the Catholics, whether by eliding them with the Donatist hate-figure that they themselves had

${ }^{81}$ Cf. J. R. Lyman, 'A topography of heresy: mapping the rhetorical creation of Arianism', in M. R. Barnes and D. H. Williams (eds), Arianism after Arius: essays on the development of the fourth century Trinitarian conflicts, Edinburgh 1993, 45-62.

${ }^{82}$ For the pen-picture see Epitome Carthaginiensis, ed. Mommsen, 495; for the

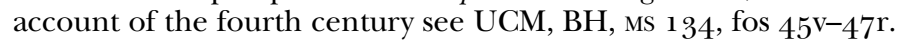


created, or justifying their punishment through their coercion of those dissident African Christians. All of these writers represented themselves as participants in a continuous history of African Christianity stretching back into the distant past. In so doing, they perpetuated a conflict-and heretical opponents-more familiar to themselves and to their imagined audiences.

Jnl of Ecclesiastical History, Vol. 65, No. 3, July 2014. (C) Cambridge University Press 2014 doi:10.1017/Soo22046914000682

\section{The Eusebius Essay Prize}

The Eusebius Essay Prize, of $£ 5$ oo, is offered annually for the best essay submitted on a subject connected with any aspect of early Christian history, broadly understood as including the first seven centuries AD/ CE. Scholars in any relevant discipline (theology, classics, late antique studies, Middle Eastern Studies etc.), whether established in their field or graduate students, are encouraged to enter the competition. Submissions from younger scholars are particularly welcomed. The essay should not exceed 8,0oo words, including footnotes, and for 2014 should be submitted by 30 September. A judgement will be made at the end of November (the editors reserve the right not to award the prize if no essay of significant quality is submitted). The essay of the successful candidate will be published in the Journal, probably in the number appearing in July 2015. Other submissions entered into the competition may also be recommended for publication. All essays should be sent as two hard copies, prepared to journal style, to Mrs Anne Waites, Journal of Ecclesiastical History, Robinson College, Cambridge $\mathrm{CB}_{3}$ 9AN. 